other regions. A model of the largest platinum nugget found in the Urals and crystals of sulvanite (sulpho-vanadate of copper) from Utah have been purchased. The herbarium of the Royal Botanical Society of London has been presented by the Council to the Department of Botany. A valuable collection of about eleven thousand European mosses has been presented by the Rev. P. G. Rhodes; and Mrs. T. G. Elliott has presented about four hundred specimens of Ceylon ferns collected by her father, the late Rev. E. N. Freeman. The latter is of special interest as being the first large collection of localised Ceylon ferns received by the Department.

\section{Hippophagy in Ancient Palestine}

AN interim report from Sir Flinders Petrie on his excavations at Tell-el-Ajjul in southern Palestine, in the Times of Feb. 24, dwells on the significance of the exploration of this area for the history of the Hyksos domination in Egypt and Palestine. "The south of Palestine", it is said, "proves to be the best source for understanding this great catastrophe of ancient times." The date of the city is now fixed by scarabs of Apepa I. and the names of other Hyksos kings. The work of this season has brought to light a new custom. It will be remembered that last year the remains of a horse were discovered in one of the large pit-graves on the plain below the tell. The horse was disposed in the centre, while the bodies of the members of the family lay on shelves around the pit. Now the remains of a horse have been discovered which had evidently been sacrificed and its body buried under the foundations of a large building. Near by an oven had been built for the purpose of cooking the thigh and shoulders of the victim for a feast, while another horse had been completely cut up and the bones left on the ground after it had been eaten. Sir Flinders Petrie adds the interesting comment that no other example of hippophagy has been found in the east, and in the west the practice is not known later than the stone age.

\section{Prof. W. E. Garner}

THE course of lectures on detonating substances which was to have been given at the Royal Institution on March 1, 8, and 15 by Prof. W. E. Garner, Leverhulme professor of physical chemistry in the University of Bristol, has been postponed owing to an accident to him. Prof. Garner has been engaged for some time in a research on solid explosive substances. On Thursday, Feb. 25, when he was about to remove a crystal of pure lead azide from a cardboard pill-box containing about $5 \mathrm{mgm}$. of the material, as he raised the cover of the box with his right hand, the material exploded. Two of his fingers were seriously damaged and his left hand received lesser injuries. We are glad to learn that he is making very satisfactory progress.

\section{French Exploratory Voyages}

A USEFUL chart of the world showing all the great French voyages of exploration from the fifteenth to the early nineteenth century is included in the issue of La Géographie for July-August 1931. The chart, originally prepared by $\mathbf{M}$. H. Roussilhe and L. Bergelin for the Exposition Internationale d'Anvers in 1930, is based on the original itineraries and charts of the voyages concerned, and though on a comparatively small seale, is remarkably clear. An old-world appearance is given to it by various reproductions of vessels of the periods of different voyages, taken from contemporary sourees and suitably placed on the oceans.

\section{New Land Speed Records}

ON Feb. 24, at Daytona, Florida, Sir Malcolm Campbell set up a new record for land speed in his car Blue Bird. On two runs, northwards and southwards respectively, over a measured mile, his average time gave a speed of 253.968 miles an hour, thus beating his own record made last year at the same place and in the same car by about eight miles an hour. Sir Malcolm made a further attempt on Feb. 26, but his speed over the measured mile was returned as $251 \cdot 748$ miles an hour. His average for five miles, however, worked out at $\mathbf{2 4 2 . 7 5 1}$ miles an hour, thus beating his own previous record for this distance by more than thirty miles an hour. Sir Malcolm's car Blue Bird had been fitted with a new and more powerful Napier engine of approximately 1500 h.p.

\section{Muslim Association for the Advancement of Science}

THE objects of this Association, which was inaugurated at Aligarh about a year ago, are to stimulate research work amongst Mohammedans by means of grants in aid of special laboratory apparatus, research materials, and laboratory assistance. The Association is undertaking the publication of specialised memoirs by distinguished investigators in its Proceedings, and its constitution permits the creation of research professorships and visiting lectureships as soon as sufficient funds become available. Nawab Masood Jung, vice-chancellor, and Dr. R. F. Hunter, the present holder of the Nizam chair of chemistry in the Aligarh Muslim University, are the first president and vice-president respectively, but the Association's constitution has now been extended to include representation on its council from British India, Hyderabad, and Egypt.

\section{The Hayden Memorial Gold Medal}

IT is announced that the Academy of Natural Sciences of Philadelphia has awarded the Hayden Memorial Gold Medal for 1932 to Dr. Reginald Aldworth Daly, Sturgis-Hooper professor of geology in Harvard University. This is the outstanding American award for pre-eminence in geological and palæontological research. Prof. Daly's work chiefly involves the study of igneous rocks, their genesis, and the mechanics of their intrusion into the mountains of the earth. Other of his outstanding contributions to geology are his glacial-control theory of coral reefs, his work on the eustatic shift of oceanic level, and his researches on the constitution of the earth. $\mathrm{He}$ has presented many of his ideas in popular form in his book, "Our Mobile Earth" (1926). The Hayden award, which is made every three years, was founded in 1888 by Mrs. Emma W. Hayden, of Philadelphia, as

No. 3253, Vou. 129] 
a memorial to her husband, Dr. Ferdinand V. Hayden, director of the United States Geological and Geographical Survey in the early days of that organisation.

\section{Botanic Gardens in South Africa}

IN Part 17 of the Journal of the Botanical Society of South Africa (1931) is published an excerpt from the report written by Sir Arthur Hill to the Union Government after his tour in South Africa in 1929, which was referred to in NATURE of Feb. 7, 1931, p. 217. The report states that at present, owing to lack of funds, the Director of the Kirstenbosch Botanic Garden is working single-handed and the garden staff is inadequate. This refers to 1929 , and in the present Journal the Gardens have to report a ten per cent reduction of the Government grant which they share in common with other State-aided institutions. On the whole, the moment scarcely seems propitious for the consideration of Sir Arthur Hill's suggestion that South Africa should try to maintain three botanic gardens, with the development of a sub-tropical botanic garden at Durban and a botanic garden with arboretum at Pretoria. It is good to see that the body of supporters for the Kirstenbosch gardens, provided by the Botanical Society of South Africa, continues steadily to grow in numbers. In this same report Sir Arthur Hill presses for the policy of making Table Mountain into a Nature reserve, and it is good to learn that action has now been taken by the Administrator of the Cape Province which gives complete legal protection to the flora and fauna of the Mountain.

\section{Biology and Quantum Theory}

Prof. Niels Bohr, of Copenhagen, has brought together a collection of articles dealing in a rather general way with modern physics, under the title "Atomtheorie und Naturbeschreibung" (Berlin : Julius Springer, 1931. 5.60 gold marks). Reference is made in several of the articles to the question of the relation between the development of quantum theory and the formulation of the fundamental problems of biology. The point of view which is taken is that a consideration of the new ideas and methods of physics, often essentially foreign to ordinary conceptions and experience, may indicate how the discussion of the place of living organisms in our scheme of things should be approached. Prof. Bohr directs attention to the existence of a natural limit to the investigation of life in the inevitable death of an organism which is subjected to a complete physical investigation of its atomic constitution. A recognition of the importance of such matters is perhaps becoming rather general, as we find Dr. P. A. M. Dirac grouping the problem of life with the relativistic formulation of quantum mechanics and the nature of atomic nuclei-as a "more difficult" problem-in the introduction to a paper on quantised singularities in the electromagnetic field, in the Proceedings of the Royal Society for last September, but it can scarcely be irrelevant to refer here also to Samuel Butler's ingenious treatment of a similar topic in "The Book of the Machines", sixty years ago, in "Erewhon".

No. 3253, VoL. 129]

\section{Announcements}

By an order of the Committee of Privy Council, Mr. W. S. Morrison, M.P., has been appointed a member of the Medical Research Council, on the retirement of Major A. G. Church.

Prof. G. Elliot Sмrth, professor of anatomy in University College, London, has been given the honorary degree of M.D. by the Egyptian University, Cairo, on the occasion of its first convocation, held on Feb. 27. Prof. Elliot Smith was at one time professor of anatomy in the Government Medical School, Cairo.

THE third Pedler lecture before the Chemical Society, entitled "The Life and Work of Otto Wallach", will be delivered by Prof. L. Ruzicka, of Zurich, on March 10, at 5.30 P.M. The lecture will be given in the Meeting Hall of the Institution of Mechanical Engineers, Storey's Gate, Westminster, London, S.W.1. Tickets of admission will not be required.

Ar the annual general meeting of the Association of Economic Biologists held on Feb. 26, the following officers were elected: President, Dr. W. B. Brierley; Vice-Presidents, Dr. W. R. Thompson and Mr. A. D. Cotton; Hon. Treasurer, Dr. J. Henderson Smith; Hon. Editors, Dr. W. B. Brierley and Mr. D. Ward Cutler; Hon. Secretaries, Prof. J. W. Munro and Prof. W. Brown.

We have already referred to the sixteenth Annual of the Paris Academy of Sciences (Feb. 6, p. 199), which contains a complete list of members, going back to 1795. The Academy has now issued a small volume containing a list of members and correspon. dants during the period 1666-1793 (Paris : Au Palais de l'Institut, 23, quai de Conti. 1931). This list was compiled by M. A. Lacroix, and gives the dates of birth and death, biographical notes, and posts held by the members.

Applications are invited for the following appointments, on or before the dates mentioned :-An assistant biochemist at the General Hospital, Birmingham - The House Governor, General Hospital, Birmingham (March 12). An aircraft and engine inspector under the Government of India-The High Commissioner for India, General Department, India House, Aldwych, W.C.2 (March 12). A principal of the Sheffield City Training College for Teachers-The Director of Education, Education Office, Sheffield (March 14). An assistant medical secretary of the British Medical Association-The Medical Secretary, British Medical Association, Tavistock Square, W.C.1 (March 14). A professor of education and head of the men's training department of the University College of South Wales and Monmouthshire-The Registrar, University College of South Wales, Cardiff (March 22). A professor of geology in the University of Birmingham--The Secretary, University, Birmingham (April 11). A woman lecturer in biology at Edge Hill Training College, Liverpool-The Principal, Edge Hill Training College, Liverpool (April 19). An assistant bacteriologist in the Central Tuberculosis Laboratory of the King Edward VII. Welsh National Memorial Association-The Bacteriologist, Institute of Preventive Medicine, The Parade, Cardiff. 